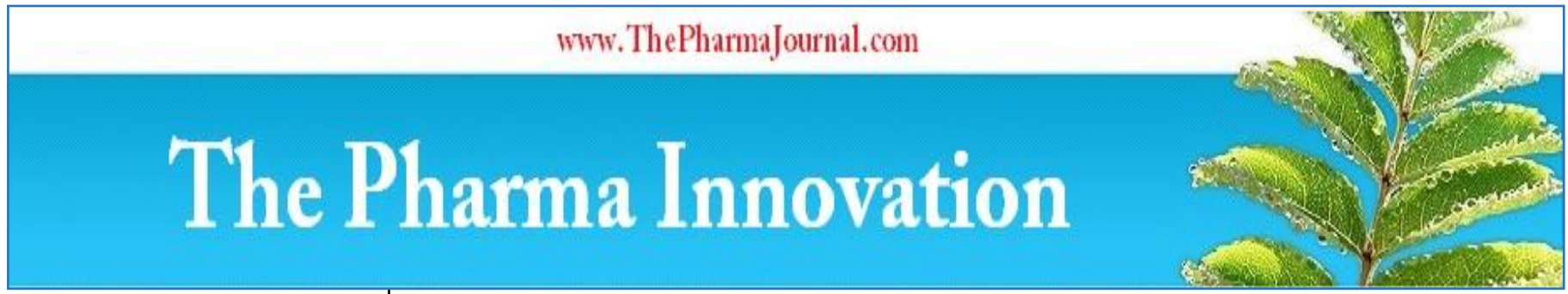

ISSN (E): 2277- 7695

ISSN (P): 2349-8242

NAAS Rating: 5.03

TPI 2020; 9(2): 460-466

(C) 2020 TPI

www.thepharmajournal.com

Received: 13-12-2019

Accepted: 15-01-2020

\section{Mitesh Gaur}

Department of Veterinary

Gynecology and Obstetrics,

College of Veterinary and Animal

Science, Navania, Vallabhnagar,

Udaipur, Rajasthan University

of Veterinary and Animal

Sciences, Bikaner, Rajasthan,

India

\section{Govind Narayan Purohit}

Department of Veterinary

Gynecology and Obstetrics,

College of Veterinary and Animal

Sciences, Bikaner, Rajasthan

University of Veterinary and

Animal Sciences, Bikaner,

Rajasthan, India

\section{Corresponding Author}

Govind Narayan Purohit

Department of Veterinary

Gynecology and Obstetrics,

College of Veterinary and Animal

Sciences, Bikaner, Rajasthan

University of Veterinary and

Animal Sciences, Bikaner,

Rajasthan, India

\section{Changes in blood flow to the umbilicus, placentomes, and uterus in Surti buffaloes during complete gestation}

\author{
Mitesh Gaur and Govind Narayan Purohit
}

DOI: https://doi.org/10.22271/tpi.2020.v9.i2i.4419

\begin{abstract}
With an objective to record the vascularity changes in the umbilicus, placentomes dimensions, and blood flow to the uterus, Surti buffaloes $(n=42)$ were inseminated during natural estrus during the breeding season and scanned by transrectal B mode and color flow mode ultrasonography every 3-4 days till Day 90 of gestation and then at 15 days interval for the complete gestation in the buffaloes that were pregnant $(\mathrm{n}=24)$. The umbilical cord color Doppler wavefronts could first be obtained on Day 46 and became increasingly distinct thereafter. The placentomes could first be identified at Day 76 of gestation. The placentome diameters increased from Day 76 till $8^{\text {th }}$ month with significant increases $(P<0.05)$ during Day 80 , then $4^{\text {th }}, 5^{\text {th }}$ and $6^{\text {th }}$ month of gestation; thereafter the increase was not significant. The vascularity of placentomes could also be recognized at Day 76 and this increased with increasing months of gestation. The blood flow to the middle uterine arteries could be identified after the $2^{\text {nd }}$ month of gestation. The resistive index (RI) values of the middle uterine artery ipsilateral to the gravid horn showed an almost linear decline with a significant $(P<0.05)$ drop in the $4^{\text {th }}$ month and $9^{\text {th }}$ month of the gestation. Similarly, RI values of the middle uterine artery contra-lateral to the gravid horn revealed significant $(P<0.05)$ decrease in $3^{\text {rd }}$ month, $5^{\text {th }}$ month and sixth month. A significant decrease in the pulsatility index (PI) values of the middle uterine artery ipsilateral to the gravid horn were observed for the $3^{\text {rd }}, 6^{\text {th }}$ and $8^{\text {th }}$ month of the gestation. However, the PI index values for the middle uterine artery contralateral to the gravid horn showed a non-significant decrease. It was concluded that the placentome dimensions can be used to diagnose the stage of gestation up to 8 months in buffaloes. The umbilical and uterine blood flow evaluation parameters during normal pregnancy increase sequentially and can serve as the basis for evaluating compromised pregnancies.
\end{abstract}

Keywords: Color doppler, vascularity, umbilicus, placentome, gestation

\section{Introduction}

Interest in the evaluation of fetal and maternal structures and their blood supply that develop during gestation in cows has been very old (Björkman, 1969) ${ }^{[3]}$. In the past, studies utilized abattoir derived material to evaluate the placentome and its microvasculature in cows (Leiser et al., 1997; Pfarrer et al., 2001) ${ }^{[30]}$ and buffaloes (Abd-Elnaeim et al., 2003; Ferreira et al., 2009). With the advent of ultrasonography maternal and fetal structures during gestation, fetal well-being and their correlations have been studied in live cattle (Des Cpteaux et al., 2006; Lazim et al., 2016; Koziol \& Moore, 2019) ${ }^{[20]}$ and buffaloes (Zambrano, 2015; Gaur and Purohit, 2018) ${ }^{[31]}$. The placentome diameters have formed the basis to predict gestational age in cattle (Blakenvoorde, 2011) and buffaloes (Singh et al., 2017) ${ }^{[35]}$. The placentome diameters increased linearly up to Day 180 of gestation but beyond Day 190 the placental dimensions decreased or remained static thereafter in cows (Adeyinka et al., 2014) ${ }^{[2]}$ thus, limiting the prediction efficacy.

Fetal survival is dependent on proper placental growth and vascularity (Vonnahme, 2012) ${ }^{[39]}$. Color Doppler evaluations have thus focused to evaluate uterine blood flow throughout gestation in cows (Bollwein et al., 2002; Pancarce et al., 2006) and to a limited extent in buffaloes (Singh et al., 2018a) ${ }^{[34]}$. The uterine blood flow is altered in compromised sheep (Wallace et al., 2002; Redmer et al., 2005; Reynolds et al., 2006) ${ }^{[33]}$ and bovine (Camacho et al., 2014) ${ }^{[8]}$ pregnancies. Several environmental factors have been shown to negatively impact placenta development and blood flow during the pregnancy, all of which can hinder offspring health and vigor (Lemley, 2017) ${ }^{[25]}$. Uterine blood flow was found to be compromised in buffaloes with uterine torsion (Hussein, 2013; Devender et al., 2016) ${ }^{[10]}$ thus, establishing normal blood flow to placenta and uterus throughout gestation becomes important. 
A recent study evaluated the vascularity of ovarian follicles and the corpus luteum during the estrous cycle in Surti buffaloes (Gaur \& Purohit, 2019) ${ }^{[14]}$. Studies on umbilical vasculature and blood flow to the uterus in buffalo during gestation are very few (Varughese, Brar \& Dhindsa). The umbilical cord is the structure that connects the fetus with the mother's uterus through the placenta. The umbilical arteries and vein run within this cord. A previous study on abattoir derived material showed that the umbilical cord in buffaloes was composed of 2 thick arteries and 2 thin veins (Ferreira et al., 2009) ${ }^{[12]}$. In the present study, we examined the vascularity changes in the umbilicus, placentome dimensions, and uterine blood flow throughout pregnancy in Surti buffaloes using transrectal color Doppler ultrasonography.

\section{Materials and Methods}

\subsection{Experimental animals and design}

Surti buffaloes $(n=42)$ belonging to the elite herd maintained at Livestock Research Station, Vallabhnagar, Udaipur, Rajasthan, India were included in the study during the breeding season (November 2015 to March 2016). Estrus detection was carried out by exposing females to a teaser buffalo bull early morning and late evening as described previously (Purohit \& Rao, 2018) ${ }^{[13]}$. Buffaloes in standing estrus were inseminated twice at $12 \mathrm{~h}$ intervals with frozen semen from high fertility buffalo bulls. The buffaloes were restrained in a chute and examined by transrectal B mode and Color Flow Mode (CFM) ultrasonography (Exago, ECM Noveko International Inc., Angoulème, France) equipped with a 5-7.5 MHz, linear-array transducer every 3-4 days starting from Day 15 of insemination till pregnancy confirmation at Day 30 using procedures described previously (Zambrano, 2015). The scanning was continued at the same intervals in pregnant buffaloes $(n=24)$ till Day 90 of pregnancy. Further, from Day 90 onwards pregnant buffaloes were scanned every 15 days till parturition by B-mode, CFM mode and Pulse Wave Doppler (PWD) mode to evaluate the umbilical appearance and vascularity, placentomes dimensions, and blood flow to the middle uterine artery. Four to six placentomes close to the cervix were measured using inbuilt calipers of the transrectal ultrasound. The average of all the dimensions was considered the diameter for that particular day. The images were saved and the changes in dimensions were analyzed retrospectively.

\subsection{Sonographic and Color Doppler evaluations}

Hemodynamic measurements of the uterine artery ipsilateral and contralateral to the conceptus were obtained via a color Doppler ultrasonography equipped with a 5-7.5 $\mathrm{MHz}$, transducer (Exago, ECM - Noveko International Inc., Angoulème, France). Ultrasonic evaluations were taken at the same time of day between $8 \mathrm{AM}$ and $12 \mathrm{PM}$ and lasted approximately 30 minutes per buffalo.

Briefly, the probe was inserted through the rectum, and the aorta was located. In B mode using the finger probe, the origin of the external iliac artery, ipsilateral to the gravid uterine horn, was located, and the transducer was moved caudally to locate the internal iliac artery. The umbilical artery begins as a major branch of the internal iliac and gives rise to the uterine artery (Bollwein et al., 2000) ${ }^{[6]}$. After the uterine artery was identified as a movable and pulsating artery, a longitudinal section was visualized by manually turning the transducer of the probe. The probe was aligned to the uterine artery and uterine artery hemodynamic measurements were recorded. Three similar cardiac cycle waveforms from three separate ultrasonography evaluations from each side (ipsilateral and contra-lateral uterine artery) were obtained with spectral Doppler and averaged per buffalo within a gestational day. Maternal heart rate (HR), pulsatility index (PI) and resistance index (RI) were calculated by preprogrammed Doppler software where PI = (peak systolic velocity - end-diastolic velocity)/mean velocity and RI = (peak systolic velocity - end diastolic velocity)/peak systolic velocity (Camacho, Lemley, Prezotto, Bauer, \& Freetly, 2009).

The desired images were saved in the machine itself for offline analysis. The systolic, diastolic, ratio of systolic to diastolic values (S/D), beats/minute, Resistive (RI) and Pulsatile (PI) index were recorded. The blood flow pattern in the middle uterine artery was recorded (Camacho et al., 2009). The RI and PI values for the blood flow were presented by the ultrasound machine as calculated by the inbuilt software. The recorded values were analyzed statistically.

\subsection{Statistical analysis}

The mean values and standard errors of the means for all parameters recorded were calculated. The difference between pairs of means was tested by Duncan's Multiple Range Test as modified by Kramer, (1957) ${ }^{[21]}$.

\subsection{Ethical committee approval}

The permission for conducting the research was obtained from the ethical committee of the college before experimentation with letter No CVAS/IAEC/2014-15/1-6 dated 05.05.2014.

\section{Results}

\subsection{Umbilical appearance and vascularity}

The umbilical cord was visible for the first time during sonographic scanning of pregnant Surti buffaloes on Day 38 of gestation, however; color Doppler wavefronts could first be obtained on Day 46 (Fig. 1, Fig. 2) of gestation. The umbilicus could be identified as a streak of echogenic area originating from the fetus and connecting towards the uterine wall. At Day 92 of gestation distinctly intertwined umbilical arteries and veins could be visualized (Fig. 3). Further, as the pregnancy progressed, the umbilical vessels became increasingly distinct at 5 months of gestation with 2 arteries and 2 veins visible (Fig. 4).

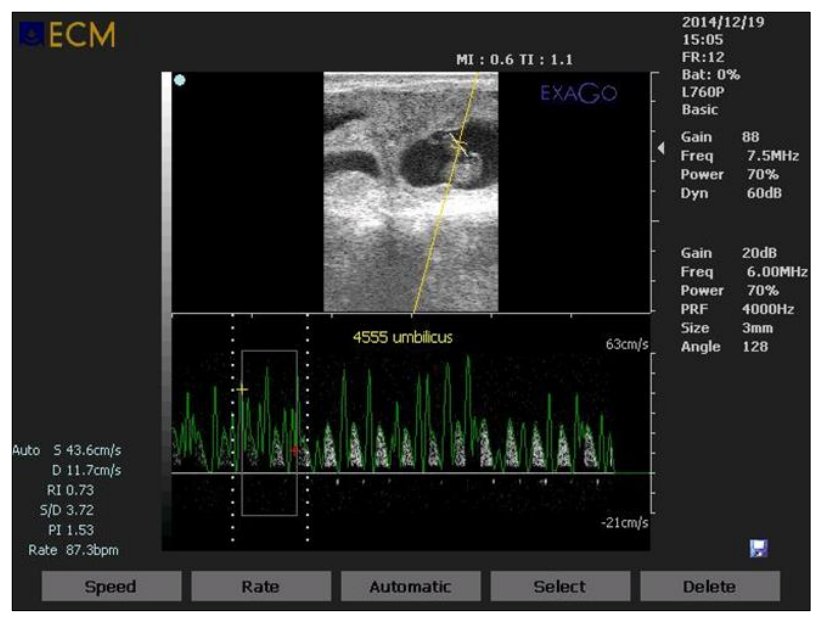

Fig 1: Doppler wave fronts of Umbilicus obtained at Day 46 of gestation. 


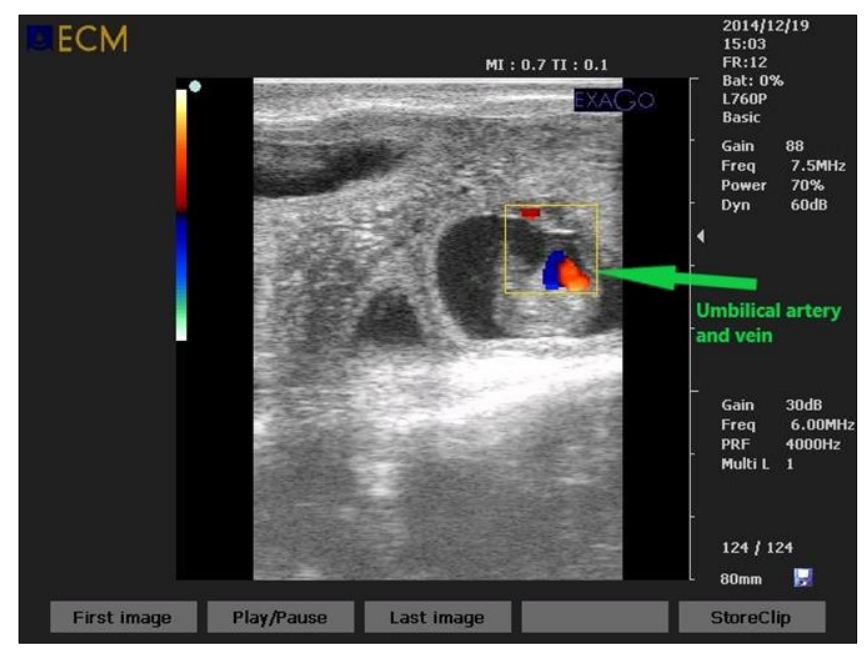

Fig 2: Color Doppler sonogram showing umbilical blood flow of Surti fetus at Day 46. The yellow box indicate the application of Color Doppler over the two dimensional Brightness mode indicating that the velocity information is presented as a color-coded overlay on top of a B-mode image. Red color indicates flow toward the transducer (artery) and blue away from the transducer (vein).

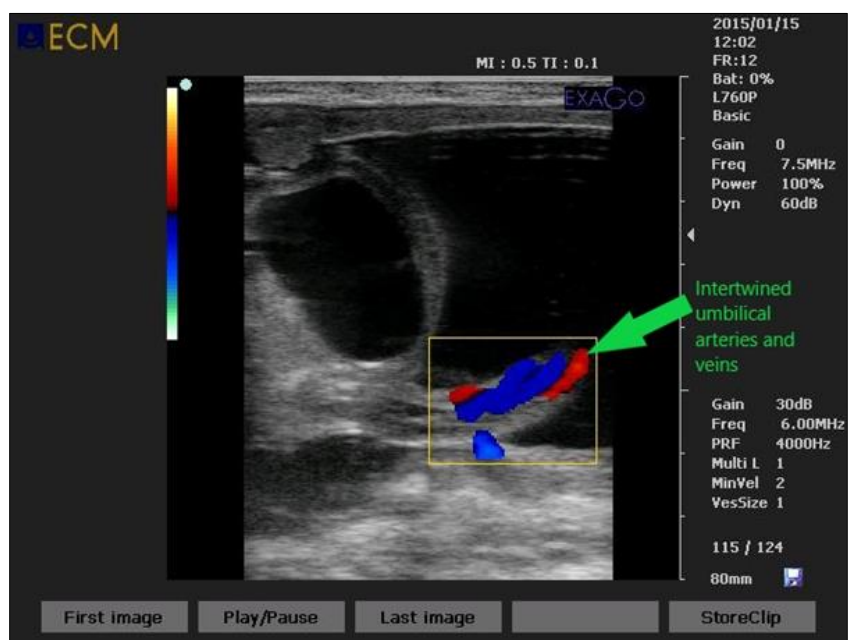

Fig 3: Color Doppler picture of umbilical blood vessels at Day 92 in a Surti buffalo. Red color indicates flow toward the transducer (artery) and blue away from the transducer (vein).

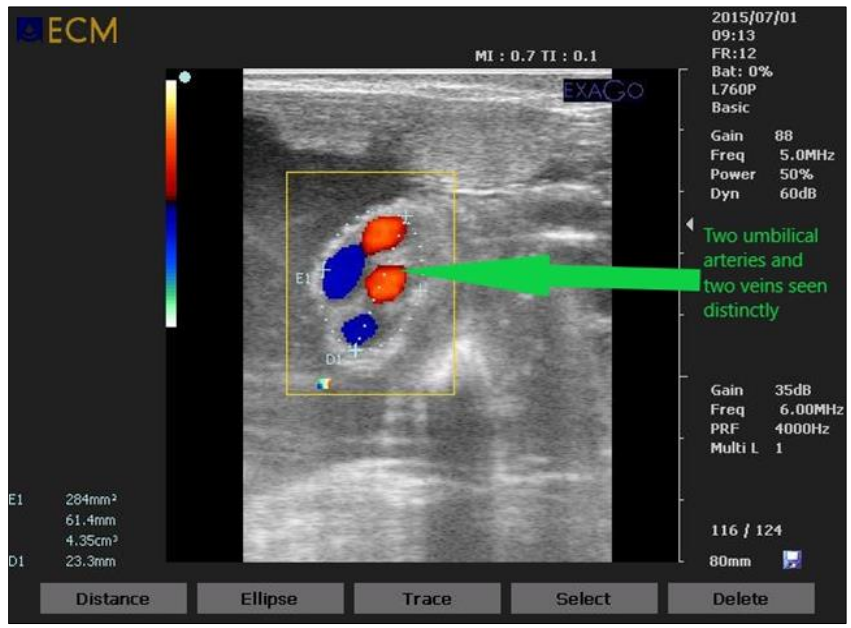

Fig 4: Color Doppler picture of umbilical arteries and veins at Day 150 of gestation. The yellow box indicate the application of Color Doppler over the two dimensional Brightness mode indicating that the velocity information is presented as a color-coded overlay on top of a B-mode image. Red color indicates flow toward the transducer (artery) and blue away from the transducer (vein). E1 denotes the measurements (area, circumference and volume, respectively) of ellipse encircling the organ measured. D1 denotes the diameter ( $\mathrm{mm}$ ) or the distance between the marked points.

\subsection{Placentomes}

In the present investigation, the placentomes were observed for the first time on Day 76 of the gestation period. The placentomes were visible as hypo-echogenic rounded elliptical or oval structure with different echogenicity sometimes with a small amount of anechoic fluid within the echogenic boundary. Color Doppler evaluations could identify the blood supply to the placentomes. Placentomes were distributed on the uterine wall and were observed surrounded by anechoic fetal fluids. Placentomes were observed as raised areas on the uterine wall and identified easily in all the animals.

The placentome diameter increased linearly from Day 75 to $8^{\text {th }}$ month with a significant increase $(P<0.05)$ on Day $80,4^{\text {th }}$, $5^{\text {th }}$, and $6^{\text {th }}$ month of gestation compared to the previous recording (Table-1). Surprisingly, the diameter of the placentome size decreased significantly after $8^{\text {th }}$ till the $9^{\text {th }}$ month of gestation period because as the pregnancy advanced it was not possible to cover the whole length of the placentome due to increased variation in location and size.

The placentome vascular blood flow could be recognized using color Doppler ultrasonography during the present study and revealed increasing vascularity with increasing months of gestation (Fig. 5).

Table 1: Average diameter of placentomes (mean \pm SEM) on various days of gestation of Surti buffaloes recorded through transrectal ultrasonography

\begin{tabular}{|c|c|}
\hline Duration of pregnancy & Diameter $(\mathbf{m m})$ \\
\hline 76 day & $7.86 \pm 0.21^{\mathrm{a}}$ \\
\hline 80 day & $9.72 \pm 0.16^{\mathrm{b}}$ \\
\hline 85 day & $10.36 \pm 0.28^{\mathrm{b}}$ \\
\hline 4 month & $28.42 \pm 0.13^{\mathrm{c}}$ \\
\hline 5 month & $36.18 \pm 0.78^{\mathrm{d}}$ \\
\hline 6 month & $44.27 \pm 2.62^{\mathrm{e}}$ \\
\hline 7 month & $53.38 \pm 4.42^{\mathrm{de}}$ \\
\hline 8 month & $64.67 \pm 7.24^{\mathrm{f}}$ \\
\hline 9 month & $43.82 \pm 4.19^{\mathrm{e}}$ \\
\hline 10 month & $58.02 \pm 6.23^{\mathrm{de}}$ \\
\hline
\end{tabular}

Mean values with different superscripts (a, b, c, d, e, f) differ significantly $(P<0.05)$ 


\subsection{Blood flow to the uterus}

The RI values of the middle uterine artery ipsilateral to the gravid horn showed an almost linear decline in the $3^{\text {rd }}$ month with a significant $d r o p(P<0.05)$ in the $4^{\text {th }}$ month and $9^{\text {th }}$ month of gestation (Table 2). Similarly, RI values of the Middle Uterine Artery contra-lateral to the gravid horn revealed a significant decrease on $3^{\text {rd }}$ month (Fig 6), $5^{\text {th }}$ month and sixth month. There was a significant decrease in the PI values of the middle uterine artery ipsilateral to the gravid horn for the $3^{\text {rd }}, 6^{\text {th }}$ and $8^{\text {th }}$ months of the gestation. However, the PI values for the middle uterine artery contralateral to the gravid horn showed a non-significant decrease over the gestation period. All the buffaloes in the study parturated normally and did not have any post-partum complications.

Table 2: Mean (mean \pm SEM) values of RI and PI of middle uterine artery observed through trans-rectal color Doppler ultrasonography in the ipsilateral (I) and contralateral (C) gravid uterine horn.

\begin{tabular}{|c|c|c|c|c|}
\hline Month of Gestation & RI-I & RI-C & PI-I & PI-C \\
\hline 2 & $1.24 \pm 0.02^{\mathrm{c}}$ & $1.13 \pm 0.02^{\mathrm{d}}$ & $1.82 \pm 0.39^{\mathrm{d}}$ & $1.32 \pm 0.41^{\mathrm{a}}$ \\
\hline 3 & $1.05 \pm 0.22^{\mathrm{c}}$ & $0.84 \pm 0.04^{\mathrm{c}}$ & $1.21 \pm 0.43 \mathrm{c}$ & $1.14 \pm 0.58^{\mathrm{a}}$ \\
\hline 4 & $0.71 \pm 0.05^{\mathrm{b}}$ & $0.81 \pm 0.03^{\mathrm{c}}$ & $1.09 \pm 0.25^{\mathrm{c}}$ & $1.26 \pm 0.16^{\mathrm{a}}$ \\
\hline 5 & $0.57 \pm 0.04^{\mathrm{b}}$ & $0.73 \pm 0.02^{\mathrm{b}}$ & $1.30 \pm 0.23^{\mathrm{c}}$ & $1.36 \pm 0.22^{\mathrm{ab}}$ \\
\hline 6 & $0.51 \pm 0.05^{\mathrm{b}}$ & $0.64 \pm 0.03^{\mathrm{a}}$ & $0.74 \pm 0.10^{\mathrm{b}}$ & $1.01 \pm 0.10^{\mathrm{a}}$ \\
\hline 7 & $0.56 \pm 0.04^{\mathrm{b}}$ & $0.69 \pm 0.02^{\mathrm{a}}$ & $0.77 \pm 0.24^{\mathrm{b}}$ & $1.31 \pm 0.32^{\mathrm{ab}}$ \\
\hline 8 & $0.43 \pm 0.03^{\mathrm{b}}$ & $0.72 \pm 0.02^{\mathrm{b}}$ & $0.51 \pm 0.06^{\mathrm{a}}$ & $1.22 \pm 0.13^{\mathrm{a}}$ \\
\hline 10 & $0.27 \pm 0.04^{\mathrm{a}}$ & $0.63 \pm 0.01^{\mathrm{a}}$ & $0.54 \pm 0.06^{\mathrm{a}}$ & $1.06 \pm 0.06^{\mathrm{a}}$ \\
\hline
\end{tabular}

Mean values with different superscripts $(\mathrm{a}, \mathrm{b}, \mathrm{c}, \mathrm{d})$ differ significantly within column $(P<0.05)$

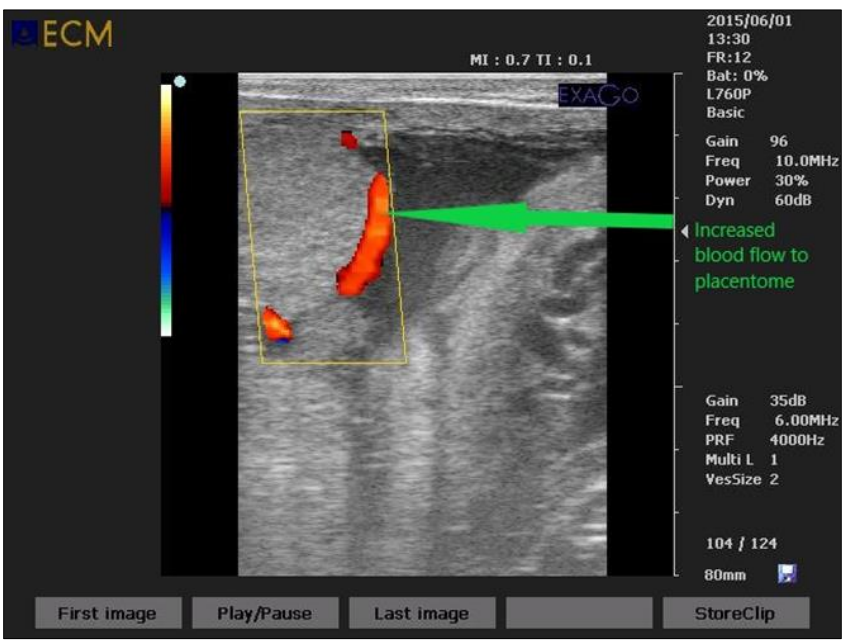

Fig 5: Placentome with increased vascularity at $7^{\text {th }}$ month of gestation. The yellow box indicate the complete observable placentomes.

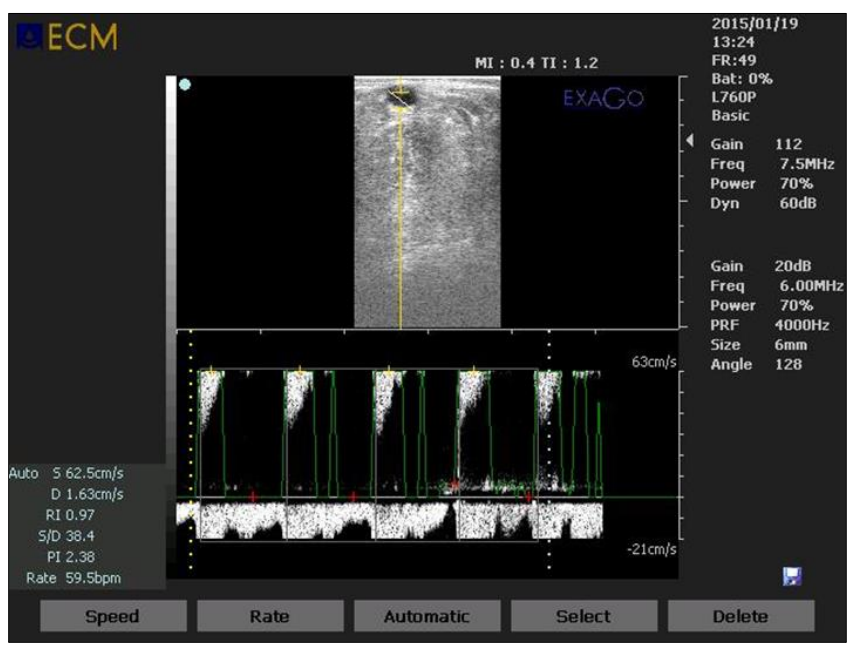

Fig 6: Middle uterine artery wave forms at Day 89 of gestation in the gravid uterine horn.

\section{Discussion}

In the present investigation, the fetal umbilical cord was first visible on Day 38 of gestation and the color Doppler wave fronts of the umbilical cord were first visible on Day 46 of gestation. Similar to the present study a previous study in Murrah buffaloes recorded the appearance of the umbilical cord at Day 38 of gestation (Singh et al., 2018b). However, Ferreira et al. (2009) ${ }^{[12]}$ observed umbilical cord around $40.25 \pm 2.76$ days of gestation period which was slightly later than the present study. The appearance of vascularity of the umbilical cord at Day 46 and sequential increase till 5 months of gestation has been sparsely demonstrated in previous studies in buffalo. The distinct appearance of 2 umbilical arteries and 2 umbilical veins is a confirmation of a previous report on abattoir derived buffalo umbilicus (Ferreira et al., 2009) ${ }^{[12]}$. Using trans-abdominal color Doppler ultrasound evaluations a recent study on Murrah buffaloes (Singh et al., 2018a) recorded minor changes in the RI and PI of umbilical blood flow in different months of gestation, however, a significant drop was recorded during the $9^{\text {th }}$ month of gestation.

In the present study, the placentomes could first be identified on Day 75 of gestation with visible vascularity. Similar to the present study previous studies have recorded the first appearance of placentomes at 70-75 days of gestation in buffaloes (Ferreira et al., 2009; Groza et al., 2012; Singh et al., 2018b) [36]. Placentomes were visible as echogenic structures with oval to elliptical shape on the uterine wall. The placentomes were surrounded by anehogenic fetal fluids. The placentome diameter could be measured at this time. The placentome diameter increased significantly up to the $8^{\text {th }}$ month of gestation. Thus, placentomes dimensions can be used to calculate gestational age up to 8 months of gestation. In cattle, the placentomes diameter increased linearly up to Day 190 of gestation but after this period till 280 days of gestation, the increase was not significant (Laven \& Peters, 2001; Adeyinka et al., 2014. Similarly, Singh et al. (2017) found a decrease in the placentomes diameter after the $8^{\text {th }}$ month of gestation in Murrah buffaloes.

The vascularity of observed placentomes increased sequentially as observed in CFM modes of ultrasound in the present study. The altered vascularity in the placentomes recorded during the present study correlates well with previous findings that the blood flow to the bovine cotyledons are altered throughout gestation and can be used to predict compromised pregnancies (Reynolds et al., 2006) ${ }^{[33]}$. The 
placental attachments undergo altered angiogenesis under the changing fetal and uterine growth during the entire pregnancy (Miles, Farin, Rodriguez, Alexander, \& Farin, 2004) ${ }^{[27] .}$

The uterine blood flow measured as RI is one of the most important indices that indicate vascular perfusion of the tissue and is recommended usually for low resistance vascular beds with continuous blood flow during diastole. The resistance index has a negative relationship with vascular perfusion i.e. decreasing resistance increases vascular perfusion and viceversa. The pulsatility (Gosling index) index (PI) is used to describe the difference between peak systolic velocity (PSV) and end-diastolic velocity (EDV) of the blood pulse in the vessel at the level of the examination gate (Gosling et al., 1971) ${ }^{[15]}$. Increased PI indicates a decrease in tissue perfusion and vice-versa. As the relation of PI to RI is positive, a recommendation of one of these indices is assumed to be sufficient. The pulsatility index is more suitable than the RI when the flow is absent during all or part of diastole (Dickey, 1997) ${ }^{[11]}$. The usefulness of PI and RI as Doppler indices in most color Doppler studies is that these are not affected by both Doppler angle and diameter of the blood vessel, and are affected only by the blood flow rate (Maulik, 1993) ${ }^{[26]}$. PI and RI provide important information to enable the researcher or the clinician to understand the extent of vascular perfusion (Urban, Bernal, \& Greenleaf, 2007) ${ }^{[37]}$.

In the present study, the RI of middle uterine artery ipsilateral to the gravid horn decreased significantly in the $4^{\text {th }}$ month over $2^{\text {nd }}$ month and then at the $9^{\text {th }}$ month of gestation. Similarly, the PI of middle uterine artery ipsilateral to the gravid uterine horn decreased significantly on the $3^{\text {rd }}$ month, $6^{\text {th }}$ and $8^{\text {th }}$ month of gestation. This suggests that the blood flow volume and pulsatility increased progressively. A significant increase $(\mathrm{P}<0.05)$ during the $8^{\text {th }}$ and $9^{\text {th }}$ month of gestation probably reflects the maximum blood perfusion to the uterus during this time. Similarly, Singh et al. (Singh et al., 2018b) ${ }^{[36]}$ have recorded a significant increase in the blood flow to the uterus at the $9^{\text {th }}$ month of gestation in pregnant Murrah buffaloes. Devender et al. (2016) ${ }^{[10]}$. recorded RI and PI values in the middle uterine artery in torsion affected buffaloes and observed increased values than normal pregnant buffaloes. Varughese et al. (2013) reported that resistance index values were positively correlated with the pulsatility index but negatively correlated with all other parameters for both arteries ipsilateral and contralateral to the fetus. There was a reduction in resistance index with significant advancement of pregnancy in middle uterine arteries in pregnant buffaloes. In the work by Hussein, (Hussein, 2013), the RI values of 8-month pregnant Egyptian buffaloes were $0.98 \pm 0.24$ and $1.04 \pm 0.24$ (mean + SEM) in the ipsilateral and contralateral uterine horns respectively. Bollwein et al. (2004) [7] reported that there were no significant differences in RI values between uterine arteries ipsilateral and contralateral to the conceptus in the mare and the mean RI values decreased by more than half during pregnancy. The comparison of uterine blood flow to the gravid and non-gravid uterine horns in Holstein cows at 225, 248 and 266 days of gestation revealed that the uterine blood flow to the gravid uterine horns was significantly higher compared to the non-gravid horns (Nishida, Hosoda, Matsuyama, \& Ishida, 2006). The perfusion rate (PR) increased $(\mathrm{P}<0.001)$, and the blood flow volume $(\mathrm{BFV})$ of the ipsilateral uterine artery decreased between 4.5 and 0.5 weeks pre-partum in cows (Kim-Egloff, Hässig, Bruckmaier, $\&$ Bleul, 2016). A study in cattle mentioned that there was a linear increase in uterine BFV in lactating Holstein cows during the second half of pregnancy with marked individual variations (Herzog, Koerte, Flachowsky, \& Bollwein, 2011). The normal parturition in all the buffaloes in the study reflects that in buffaloes with the normal progression of pregnancy the blood flow to the uterus should increase sequentially.

\section{Conclusions}

In summary, we showed that the placentome dimensions can be used to diagnose the gestational age for up to 8 months. The blood supply to the umbilicus, placentomes, and uterus increases with gestation in Surti buffaloes and umbilical and uterine blood flow evaluation parameters during normal pregnancy can serve as the basis for evaluating compromised pregnancies.

\section{Acknowledgement}

The necessary help and permission by the Dean Veterinary College Navania is thankfully acknowledged.

\section{References}

1. Abd-Elnaeim MMM, Miglino MA, Pfarrer C, Leiser R. Microvascular architecture of the fetal cotyledons in water buffaloes (Bubalus bubalis) during different stages of pregnancy. Annals of Anatomy. 2003; 185:325-334. https://doi.org/10.1016/S0940-9602(03)80053-5

2. Adeyinka FD, Laven RA, Lawrence KE, van den Bosch M, Blankenvoorde G, Parkinson TJ. Association between placentome size, measured using transrectal ultrasonography, and gestational age in cattle. New Zealand Veterinary Journal. 2014; 62(2):51-56. https://doi.org/10.1080/00480169.2013.832620

3. Björkman NH. Light and electron microscopic studies on cellular alterations in the normal bovine placentome. The Anatomical Record. 1969; 163(1):17-29. https://doi.org/10.1002/ar.1091630103

4. Blankenvoorde GHH. Determination of gestational age in dairy cattle using transrectal ultrasound measurements of placentome size. Doctoral Thesis Utrecht University, Netherlands, 2011. https://dspace.library.uu.nl/handle/1874/211905

5. Bollwein H, Baumgartner U, Stolla R. Transrectal Doppler sonography of uterine blood flow in cows during pregnancy. Theriogenology. 2002; 57:2053-2061. doi:10.1016/s0093-691x(02)00706-9

6. Bollwein H, Meyer HH, Maierl J, Weber F, Baumgartner U, Stolla R et al. Transrectal Doppler sonography of uterine blood flow. Theriogenology. 2000; 53(8):15411552. doi : $10.1016 / \mathrm{s} 0093-691 \times(00) 00296-x$

7. Bollwein H, Weber F, Woschee I, Stolla R. Transrectal Doppler sonography of uterine and umbilical blood flow during pregnancy in mares. Theriogenology. 2004; 61:499-509. DOI:10.1016/s0093-691x(03)00225-5

8. Camacho LE, Lemley CO, Prezotto LD, Bauer ML, Freetly HC. Effects of maternal nutrient restriction followed by re-alimentation during mid-gestation on uterine blood flow in beef cows. Theriogenology. 2014; 81(9):1248-1256. doi: 10.1016/j.theriogenology. 2014.02.006.

9. DesCôteaux L, Carrière PD, Durocher J. Ultrasonography of the reproductive system of the cow: basic principles, practical uses and economic aspects of this diagnostic tool in dairy production. Wold Buiatrics Congress. 2006; 143-164. https://doi.org/10.1002/9781118974520.ch10 
10. Devender Chandolia RK, Pandey AK, Yadav V, Kumar P, Dalal J. Transabdominal color doppler ultrasonography: A relevant approach for assessment of effects of uterine torsion in buffaloes. Veterinary World. 2016; 9(8):842-849.

https://doi.org/10.14202/vetworld.2016.842-849

11. Dickey RP. Doppler ultrasound investigation of uterine and ovarian blood flow in infertility and early pregnancy. Human Reproduction Update. 1997; 3(5):467-503. https://doi.org/10.1093/humupd/3.5.467

12. Ferreira GJ, Branco É, Cabral R, Gregores GB, Fioretto ET, de Lima AR et al. Morphological aspects of buffaloes (Bubalus bubalis) umbilical cord. Pesquisa Veterinária Brasileira. 2009; 29,788-792. http://dx.doi.org/10.1590/S0100-736X2009001000002

13. Gaur M, Purohit GN. Ultrasonographic Fetometry and Fetal Structures during Early Pregnancy in Surti Buffaloes. Indian Journal of Veterinary Science and Biotechnology. 2018; 14:39-43. doi: 10.21887/ijvsbt.14.2.9

14. Gaur M, Purohit GN. Follicular dynamics and colour Doppler vascularity evaluations of follicles and corpus luteum in relation to plasma progesterone during the oestrous cycle of Surti buffaloes. Reproduction in Domestic Animals. 2019; 54(3):585-594. https://doi.org/10.1111/rda.13400

15. Gosling RG, Dunbar G, King DH, Newman DL, Side CD, Woodcock JP et al. The Quantitative Analysis of Occlusive Peripheral Arterial Disease By a Non-Intrusive Ultrasonic Technique. Angiology. 1971; 22(1):52-55. https://doi.org/10.1177/000331977102200109

16. Groza I, Tomai G, Cenariu M. Ultrasonography, a Modern Tool for Pregnancy Diagnosis and Identification of Fetal Structures in Domestic Buffaloes, Bulletin of University of Agricultural Sciences and Veterinary Medicine Cluj-Napoca - Veterinary Medicine. 2012; 69:360-367. /10.15835/buasvmcn-vm:69:1-2:8864.

17. Herzog K, Koerte J, Flachowsky G, Bollwein $H$. Variability of uterine blood flow in lactating cows during the second half of gestation. Theriogenology. 2011; 75:1688-1694.

doi: 10.1016/j.theriogenology.2010.12.033

18. Hussein HA. Validation of color Doppler ultrasonography for evaluating the uterine blood flow and perfusion during late normal pregnancy and uterine torsion in buffaloes. Theriogenology. 2013; 79(7):10451053.

https://doi.org/10.1016/j.theriogenology.2013.01.021

19. Kim-Egloff C, Hässig M, Bruckmaier R, Bleul U. Doppler sonographic examination of uterine and placental perfusion in cows in the last month of gestation and effects of epidural anesthesia and isoxsuprine. Theriogenology. 2016; 85(5):986-998.

https://doi.org/10.1016/j.theriogenology.2015.11.010

20. Koziol J, Moore G. Transrectal ultrasound of the combined thickness of the uterus and interplacentome region in healthy pregnant Holstein cows. Veterinary Journal. 2019; 249:80-81.

doi: 10.1016/j.tvj1.2019.05.011.

21. Kramer CR. Extension of multiple range tests to group correlated means. Biometrics. 1957; 13:13-18. https://doi.org/10.2307/3001898

22. Laven RA, Peters AR. Gross morphometry of the bovine placentome during gestation, Reproduction in Domestic
Animals. 2001; 36:289-296.

https://doi.org/10.1046/j.1439-0531.2001.00297.x

23. Lazim EH, Alrawi HM, Aziz DM. Relationship between gestational age and transabdominal ultrasonographic measurements of fetus and uterus during the 2nd and 3rd trimester of gestation in cows. Asian Pacific Journal of Reproduction. 2016; 5:326-330.

doi:10.1016/j.apjr.2016.06.010

24. Leiser R, Krebs C, Klisch K, Ebert B, Dantzer V, Schuler G, Hoffmann B. Fetal villosity and microvasculature of the bovine placentome. Journal of Anatomy. 1997; 191:517-527.

https://doi.org/10.1046/j.1469-7580.1997.19140517.x

25. Lemley CO. Investigating reproductive organ blood flow and blood perfusion to ensure healthy offspring. Animal Frontiers. 2017; 7(3):18-24. https://doi.org/10.2527/af.2017-0124

26. Maulik D. Hemodynamic interpretation of the arterial Doppler waveform. Ultrasound in Obstetrics and Gynecology. 1993; 3(3):219-227. https://doi.org/10.1046/j.1469-0705.1993.03030219.x

27. Miles JR, Farin CE, Rodriguez KF, Alexander JE, Farin PW. Angiogenesis and Morphometry of Bovine Placentas in Late Gestation from Embryos Produced In Vivo or In Vitro1. Biology of Reproduction. 2004; 71(6):1919-1926. https://doi.org/10.1095/biolreprod.104.031427

28. Nishida T, Hosoda K, Matsuyama H, Ishida M. Collateral uterine blood flow in Holstein cows during the third trimester of pregnancy. Journal of Reproduction and Development. 2006; 52(5):663-668. https://doi.org/10.1262/jrd.17083

29. Panarace M, Garnil C, Marfil M, Jauregui G, Lagioia J, Luther E. Transrectal Doppler sonography for evaluation of uterine blood flow throughout pregnancy in 13 cows. Theriogenology. 2006; 66:2113-2119. doi:10.1016/j.theriogenology.2006.03.040

30. Pfarrer C, Ebert B, Miglino MA, Klisch K, Leiser R. The three-dimensional feto-maternal vascular interrelationship during early bovine placental development: A scanning electron microscopical study. Journal of Anatomy. 2001; 198(5):591-602. https://doi.org/10.1017/S0021878201007701

31. Purohit GN, Rao TKS. Estrus Detection in Buffaloes. In GN. Purohit (Ed.), Bubaline Theriogenology). Ithaca, NY: International Veterinary Information Service, 2018, $1-26$

32. Redmer DA, Aitken RP, Milne JS, Reynolds LP, Wallace JM. Influence of maternal nutrition on messenger RNA expression of placental angiogenic factors and their receptors at midgestation in adolescent sheep. Biology of Reproduction. 2005; 72(4):1004-1009.

33. Reynolds LP, Caton JS, Redmer DA, Grazul-Bilska AT, Vonnahme KA, Borowicz PP et al. Evidence for altered placental blood flow and vascularity in compromised pregnancies. Journal of Physiology. 2006; 572(1):51-58. https://doi.org/10.1113/jphysiol.2005.104430

34. Singh G, Chandolia RK, Dutt R, Saini A, Malik RK. Characteristics of middle uterine artery and fetal umbilical blood flow in pregnant Murrah buffalo. The Indian Journal of Animal Reproduction. 2018a; 39(1):1114.

35. Singh G, Chandolia R, Dutt R, Saini A, Dalal J, Malik R. Trans-Abdominal Ultrasonography during Second and Third Trimester in Murrah Buffaloes. International 
Journal of Livestock Research. 2017; 7(12):174-185. https://doi.org/10.5455/ijlr.20170426104230

36. Singh G, Chandolia RK, Dutt R, Dalal J, Saini A, Malik RK. Two dimensional trans-rectal ultrasonographic studies in early pregnant murrah buffaloes. Indian Journal of Animal Sciences. 2018b; 88(1):59-64.

37. Urban MW, Bernal M, Greenleaf JF. Phase aberration correction using ultrasound radiation force and vibrometry optimization. IEEE Ultrasonics Ferroelectrics and Frequency Control Society. 2007; 54:1142-1153.

38. Varughese EE, Brar PS, Dhindsa SS. Uterine blood flow during various stages of pregnancy in dairy buffaloes using transrectal Doppler ultrasonography. Animal Reproduction Science. 2013; 140(1-2):34-39. https://doi.org/10.1016/j.anireprosci.2013.05.011

39. Vonnahme KA. How the maternal environment impacts fetal and placental development: implications for livestock production. Animal Reproduction International Biology. 2012; 9:789-797.

40. Wallace JM, Bourke DA, Aitken RP, Leitch N, Hay WW. Blood flows and nutrient uptakes in growthrestricted pregnancies induced by over nourishing adolescent sheep. American Journal of Physiology Regulatory Integrative and Comparative Physiology. 2002; 282(4 51-4):1027-1036.

41. Zambrano GJ. Reproductive Application of Ultrasound in the Female Buffalo (Bubalus bubalis). In GN. Purohit (Ed.), Bubaline Theriogenology, Ithaca, NY: International Veterinary Information Service. Last updated: 18-Dec-2015; A5709.1215, 2015, 1-18). 